\title{
Assessing the application efficiency of organic fiber filler for foamed fiber concrete
}

\author{
Tatiana Golova ${ }^{1, *}$, Inna Magerramova ${ }^{1}$, Natalia Andreeva ${ }^{1}$ \\ ${ }^{1}$ National Research Nuclear University MEPhI (Moscow Engineering Physics Institute), Balakovo \\ Engineering and Technology Institute (branch), 140, Chapaeva, Balakovo, 413800, Russia
}

\begin{abstract}
The feasibility of using organic fiber filler as reinforcing fibers for non-autoclaved foamed concrete composites is discussed in the paper. The aim of the research is to analyze the factors affecting the strength and thermal insulation properties of foamed concrete and fiber concrete. Moreover, the study purpose is to obtain correlations for predicting the technological properties of thermal insulation foamed concrete and fiber concrete mixtures. The results of studying the indicators of compressive strength, bending, and thermal conductivity of a foamed fiber concrete composition with organic fiber filler are presented. The optimal sizes and amounts of organic filler made of straw are determined. The introduction of $15-30 \%$ of the total mixture mass is the most effective. In this case, the compressive strength increases by $28 \%$, and the value of the thermal conductivity coefficient decreases by $8 \%$ compared with the control samples.
\end{abstract}

\section{Introduction}

The construction of modern buildings and structures requires the use of concrete with high performance properties. One way to improve the performance of concrete is to reinforce it with various metallic and non-metallic fibers of mineral or organic origin.

The prospect of using non-metallic fibers as dispersed reinforcement has been confirmed by studies of various authors $[1-4,11,13,14]$. Synthetic fibers have received the greatest use in fiber concrete. Moreover, the low demand for organic fibers in fiber concrete is substantiated by the insufficient knowledge of their wear resistance and serviceability under various operating conditions in a concrete matrix. The widespread introduction of this material is hindered by the lack of technological solutions aimed at modifying organic fibers with normalized physical and mechanical characteristics, as well as regulatory documents for their design $[5,6,7,8,12]$.

The current economic situation in the country determines a new approach to selecting the effective building products based on local materials for housing construction. High prices for fuel, mineral and organic raw materials, and the high cost of transport are reflected, first of all, in the most voluminous and large-capacity building materials, which are wall products and structures. The need for energy saving required the creation and implementation of new

\footnotetext{
* Corresponding author: emelyanova-tanya@mail.ru
} 
technologies in the building materials industry. One of the promising areas is the work on improving the production of non-autoclave foamed concrete composites (NAFC) [9, 10]. The production of thermophysically effective cellular composites is problematic due to the complexity of providing a stable fine-grained cellular structure and high strength, which depend on the formulation and technological factors. Expanding the implementation of NAFC is also constrained by the lack of knowledge on the impact of a set of external influences on the structural durability and reliability of structures and products made of it.

Development of an effective technology for the production of NAFC is particularly important due to the urgency of the problem, the technology should take into account the influence of production factors on the synthesis of the structure and its construction and technological characteristics. One of the rational ways for solving this problem can be fiber reinforcement with various types of fibers. Fiber reinforcement provides the opportunity to obtain the optimal structure, characterized by reduced permeability and improved performance properties. The goal of these studies is to analyze factors affecting the strength and heat-insulating properties of foamed concrete and fiber concrete, as well as to obtain dependencies for predicting the technological properties of heat insulation foamed concrete and fiber concrete mixture. The operational properties of heat-insulating NAFCs depend on their crack resistance. It is possible to increase the crack resistance of NAFCs by reinforcing them with fibers with arbitrary volume orientation, which contributes to an increase in strength characteristics and a decrease in shrinkage deformations. The latter is the most important in the technology of NAFCs. Asbestos, alkali-resistant glass fiber, basalt, diabase and polypropylene fibers, as well as carbon fiber materials are used to reinforce cellular composites. However, a consensus on the optimal ratio between the NAFC components and the durability of products made of these composites has not yet been reached.

\section{Experimental research}

Experimental studies of the NAFC compositions reinforced with organic fiber filler were performed. The studies were carried out using standard methods of testing the physical, mechanical and operational properties on the basis of the certified laboratory "Operational Reliability of Building Materials and Structures" of the Balakovo Engineering and Technology Institute (a branch of the National Research Nuclear University MEPhI).

In order to develop effective compositions, several materials were used. The first is Portland cement mark M 500, which meets the requirements of GOST 10178-85 "Portlandtsement i shlakoportlandtsement". Its characteristics are as follows: average activity at the age of 3 days is $28 \pm 2 \mathrm{MPa}$, normal density of cement paste is $25,0 \pm 1.0 \%, \mathrm{C}_{3} \mathrm{~S}$ clinker characteristic is $63.79 \pm 2 \%, \mathrm{C}_{2} \mathrm{~S}-17.43 \pm 2 \%, \mathrm{C}_{3} \mathrm{~A}-5.94 \% \pm 1 \%, \mathrm{C}_{4} \mathrm{Al}-11.79 \% \pm 1 \%$. The sand from the Devichi gorki quarry in Balakovo was used as a siliceous component with a low fineness modulus $\mathrm{M}_{\mathrm{f}}=1.13$, a bulk density of $1310 \mathrm{~kg} / \mathrm{cm}^{3}$, and clay particles content of $0.9 \%$. The characteristic of the fibrous filler, which is rye straw, is $L_{\text {fiber }}=9-17 \mathrm{~mm}, \mathrm{~d}_{\text {fiber }}$ $=1.5-2 \mathrm{~mm}$, density is $120 \mathrm{~kg} / \mathrm{m}^{3}$. Foam generator PB-2000. The consumption of materials per $1 \mathrm{~m} 3$ of the mixture is presented in table 1 .

Table 1. Composition of non-autoclave foam concrete with organic fiber filler per $1 \mathrm{~m}^{3}$ of mixture

\begin{tabular}{|c|c|c|c|c|c|}
\hline Composition No & Cement, kg & Sand, kg & Organic filler, kg & $\begin{array}{c}\text { Foam } \\
\text { generator, } \mathrm{ml}\end{array}$ & w/s \\
\hline Sample No.1 & 310 & 210 & 171 & 715 & 0.52 \\
\hline Sample No. 2 & 310 & 210 & 139 & 715 & 0.50 \\
\hline Sample No. 3 & 310 & 210 & 77.5 & 715 & 0.47 \\
\hline Sample No. 4 & 310 & 210 & 46.5 & 715 & 0.45 \\
\hline Sample No. 5 & 310 & 210 & - & 715 & 0.43 \\
\hline
\end{tabular}


Rye straw is customary used as an organic filler. This type of filler is an annually renewable environmentally friendly product. At the same time, straw, like wood, has a tubular structure, the hollow tubular stems of which can withstand high temperature drops without violating the humidity regime.

In order to ensure the joint work of organic fiber in the structure of the fiber-reinforced concrete matrix, the filler was previously modified in a suspension of gaize, water and liquid glass. Swelling of the straw filler occurred in the sand-cement suspension of the cellular composite, followed by its separation into fibers and their enveloping by a cement paste. An arbitrary orientation of the fibers and their volume distribution was formed during stirring.

In the process of setting and hardening, the three-dimensional silica-oxygen skeleton of the sand was deformed by the $\mathrm{Ca}^{2+}, \mathrm{Mg}^{2+}, \mathrm{Fe}^{3+}, \mathrm{Al}^{3+}$ cations released during the hydration of Portland cement minerals. As a result, one-dimensional, two-dimensional chain motifs and an orthosilicate motif formed in the three-dimensional structure.

The sample preparation technology included molding in blocks of 400x200x200 mm in size and compaction of a foamed fiber reinforced mixture on a vibrating table, which contributed to a more uniform distribution of fibers and a uniform structure.

\section{The results of experimental studies}

The study of strength characteristics was carried out using cubes and beams, sawn from blocks with dimensions of 400×200x200 mm after foamed fiber concrete reached its design strength under natural hardening conditions. Tests for axial compression and tension were carried out according to GOST 28570-90 "Betony. Metody opredeleniia prochnosti po obraztsam, otobrannym iz konstruktsii" for 21 prototypes of foamed concrete (control sample No. 5) and foamed fiber concrete with organic fiber (Fig. 1). The compressive strength was determined using cube samples with an edge size of $150 \mathrm{~mm}$. The direction of the compressive load is perpendicular to the direction of the fill.

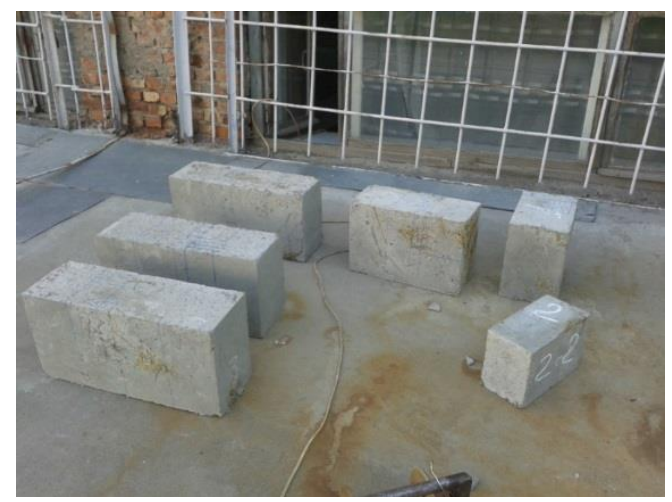

Fig. 1. Sampling from blocks

The supporting surfaces of sawn samples measuring 150x150x150 mm and 160x40x40 $\mathrm{mm}$ were ground before testing.

The compressive strength was calculated with an accuracy of $0.1 \mathrm{MPa}$ as the arithmetic average of the test results of the samples.

The following was varied in the experiments:

- type of stress-strain state (axial compression and axial tension);

- determination of the thermal conductivity coefficient;

- the type of samples sawn from the structure: cubes $150 \times 150 \times 150 \mathrm{~mm}$ and beams $160 \times 40 \times 40 \mathrm{~mm}$ (Fig. 2); 100x100x10 mm samples for determining the thermal conductivity. 
- age of concrete is more than 28 days;

- test mode with a constant speed of loading and deformation.

The strength of fiber-reinforced concrete was determined according to GOST 10180 2012 "Metody opredeleniia prochnosti po kontrolnym obraztsam razrushaiushchim metodom". A total of 15 sample cubes were tested on the MS-500 press. The test results are presented in Table 2.

Table 2. The results of the sample test for axial compression

\begin{tabular}{|c|c|c|c|c|c|}
\hline $\begin{array}{c}\text { Sample } \\
\text { name }\end{array}$ & Size, cm & $\begin{array}{l}\text { Density, } \\
\mathrm{kg} / \mathrm{m}^{3}\end{array}$ & $\mathrm{R}_{\mathrm{b}} \mathrm{MPa}$ & $\begin{array}{c}\text { B (foamed } \\
\text { concrete } \\
\text { grade)* }\end{array}$ & $\begin{array}{l}\text { Fiber distribution } \\
\text { within the sample }\end{array}$ \\
\hline $\begin{array}{c}\text { Sample } \\
\text { No. } 1\end{array}$ & $15 \times 15 \times 15$ & 1520 & $2.9(2.2 *)$ & B2.5 & \\
\hline $\begin{array}{l}\text { Sample } \\
\text { No. } 2\end{array}$ & $15 \times 15 \times 15$ & 1480 & $2.8\left(2.2^{*}\right)$ & B2.5 & \\
\hline $\begin{array}{l}\text { Sample } \\
\text { No. } 3\end{array}$ & $15 \times 15 \times 15$ & 1420 & $\begin{array}{c}3.6 \\
(3.1 *)\end{array}$ & B3.5 & \\
\hline $\begin{array}{c}\text { Sample } \\
\text { No. } 4\end{array}$ & $15 \times 15 \times 15$ & 1390 & $\begin{array}{c}5.5 \\
\left(4.6^{*}\right)\end{array}$ & B7.5 & \\
\hline $\begin{array}{l}\text { Sample } \\
\text { No. } 5 \\
\text { (control } \\
\text { sample) }\end{array}$ & $15 \times 15 \times 15$ & 1350 & $\begin{array}{c}4.1 \\
(3.1 *)\end{array}$ & B5 & \\
\hline \multicolumn{6}{|c|}{$\begin{array}{c}\text { *The grade of concrete for axial compression and tension was adopted according } \\
\text { to SP } 63.13330 .2012 \\
\text { "SNiP 52-01-2003. Betonnye i zhelezobetonnye konstruktsii. Osnovnye } \\
\text { polozheniia " }\end{array}$} \\
\hline
\end{tabular}

The compression fracture of the samples was characterized by the appearance of vertical cracks on the concrete surface (Fig 2).

The axial tensile test was carried out for samples No. 4 and No. 5, since according to the data of Table 2 they showed a sufficient result in the axial compression strength. The fracture 
of the samples by tension with bending occurred in the middle third of the span. The tensile strength in the selected samples varied in the same range. The test results are presented in Table 3.

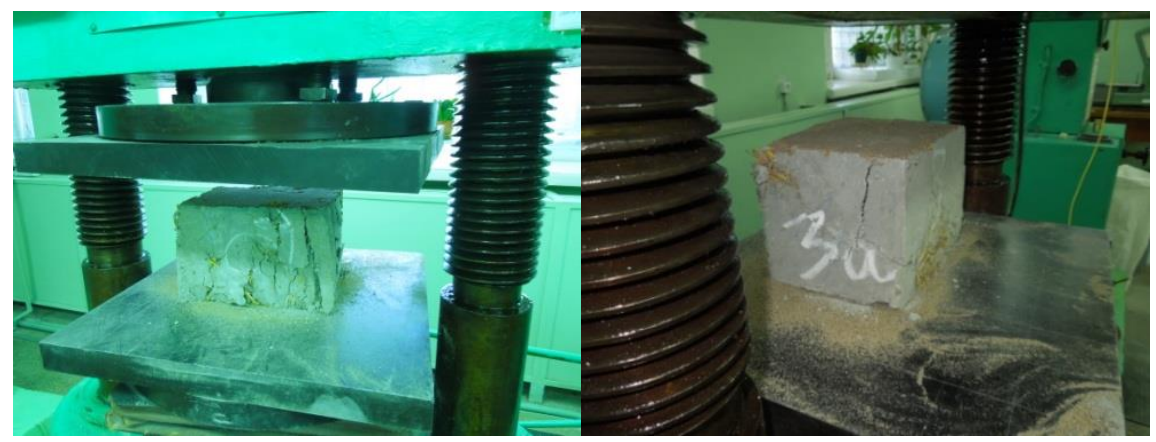

Fig. 2. Failure of samples under axial compression

Table 3. Axial tensile test results

\begin{tabular}{|c|c|c|c|c|c|}
\hline $\begin{array}{c}\text { Sample } \\
\text { name }\end{array}$ & Size, cm & $\begin{array}{c}\text { Density, } \\
\mathrm{kg} / \mathrm{m}^{3}\end{array}$ & $\begin{array}{c}\mathrm{R} \text { bt, } \\
\mathrm{MPa}\end{array}$ & $\begin{array}{c}\mathrm{B} \text { (cellular } \\
\text { concrete } \\
\text { grade) }\end{array}$ & General view of the sample \\
\hline $\begin{array}{c}\text { Sample } \\
\text { No. 4 }\end{array}$ & $16 \times 4 \times 4$ & 1390 & 0.21 & $\mathrm{~B} 1.5$ & \\
\hline $\begin{array}{c}\text { No. 5 } \\
\text { (control } \\
\text { sample) }\end{array}$ & $16 \mathrm{x} 4 \mathrm{x} 4$ & 1350 & 0.2 & $\mathrm{~B} 1.5$ & \\
\hline
\end{tabular}

The correlation between the density of the foam concrete mixture and the content of cement binder, filler, fiber reinforcement, foaming agent and water was studied. It was found that with an increase in the content of straw fibers (SF), the density of the foamed fiber concrete mixture increases.

The addition of straw fibers (SF) has an effect on the flow of foam. The effect of fiber consumption on the NAFC flow, which was determined by the Suttard viscometer, was studied. It has been established that with an increase in fiber consumption, the flow of fiberreinforced concrete decreases. For example, with a fiber consumption rate of $46.5 \mathrm{~kg} / \mathrm{m}^{3}$, the foam flow rate decreased by $19 \%$. Determining the water requirement of the fiber was carried 
out on equal-flow mixtures with a constant ratio of the volume of foam/the volume of cement paste - 1:1. It has been determined that water demand increases with an increase in SF consumption. For example, with an increase in fiber consumption from $46.5 \mathrm{~kg} / \mathrm{m}^{3}$ to 171 $\mathrm{kg} / \mathrm{m}^{3}$, water demand increased by $15.5 \%$.

The introduction of a fiber filler of optimal length $\mathrm{L}=17 \mathrm{~mm}$ reduces the shrinkage of the NAFC and increases the compressive strength by $28 \%$.

NAFCs are used for construction in various climatic conditions due to their excellent thermotechnical properties and low weight. However, when humidity of these products changes, shrinkage and cracking are observed. Based on the analysis of experimental data, two characteristic phases of volume changes can be noted. The first phase is moistening when the material is saturated with moisture over $3-5 \%$, the change in volume is small, while the primary linear dimensions are completely restored. The second fase is drying, the moisture content is from $3 \%$ to $0 \%$, deformations increase significantly, up to the final deformations (swelling). Cracks detected during the first cycle increase, leading to a final layer-by-layer fracture of the material.

The presence of linear phases of defects (dislocations), which, when a load is applied, move in the structure, increase its strength when they come to the surface of the samples. Obstacles to their movement are straw fillers.

The obtained mechanical characteristics of foamed fiber concrete using modified organic fiber filler provide the necessary bearing capacity for building elements based on them. It is necessary to assess the material during the formation and opening of cracks when calculating such elements. The crack resistance of the selected samples was determined according to GOST 29167-91 "Betony. Metody opredeleniia kharakteristiki treshchinostoikosti (viazkosti razrusheniia) pri staticheskom nagruzhenii". Initial cuts to a depth of $1.5 \mathrm{~mm}$ were made on samples 1-5, size 160x40x40 mm, by using an angle grinder UShM-230/200. The tests were carried out on the MP-500 press with a maximum force of $500 \mathrm{~kg}$. The linear dimensions of the samples were measured with an error not exceeding $1 \mathrm{~mm}, 0.01 \mathrm{~mm}$ for displacements, and the forces acting on the sample were measured with an error no more than $1 \%$ of the measured maximum force. Before the test, two loading/unloading cycles were carried out to a load of $10 \%$ of the expected maximum load. The sample loading speed was determined by the movement speed of the loading plate of the press in the range of $0.02 \ldots 0.2 \mathrm{~mm} / \mathrm{s}$. In this case, the condition was met that the test time should be at least $1 \mathrm{~min}$.

Stepwise loading of the samples with fixation of vertical displacements was carried out during the tests. According to the test results, the cracking load was established, which amounted to $12-30 \%$ of the destructive load in the range from $7.83 \mathrm{kN}$ to $37.13 \mathrm{kN}$. The maximum cracking load was found in sample beams No. 4 , and the minimum for control samples No. 5, unreinforced with an organic fibrous filler.

Wall products and structures must meet not only the requirements of strength, but also energy efficiency. The obtained foamed fiber concrete is a structural and heat-insulating material. Therefore, it is necessary to determine its thermal conductivity coefficient.

Thermal conductivity was determined for the control sample No. 5 and for the sample with the best percentage of reinforcement with foamed fiber concrete with organic fiber No. 4 by the stationary flow method on the ITP MG- 4 electronic thermal conductivity meter (Fig. 3). The selection of foamed fiber concrete samples for testing was carried out from a block with dimensions of 400x200x200 mm. Three samples were cut in sizes of 100x100x10 $\mathrm{mm}$ with the help of UShM 230/2000. The thermal conductivity of foamed fiber concrete was determined by the method of continuous heat flux. It is based on creating a heat flux directed perpendicular to the largest side of the sample of a certain thickness, measuring the density of the continious heat flux and temperatures on opposite sides of the sample. The laboratory room temperature was $20^{\circ} \mathrm{C}$. The thermal conductivity of foamed concrete and fiber concrete was determined on samples dried to constant weight at a temperature of 110 
${ }^{\circ} \mathrm{C}$ in an oven according to the method of GOST 7076-99 "Materialy i izdeliia stroitelnye. Metod opredeleniia teploprovodnosti i termicheskogo soprotivleniia pri statsionarnom teplovom rezhime". Before testing, the samples were kept in the laboratory for two hours. A sawn sample of foamed fiber concrete was placed in the heating installation (Fig. 3).

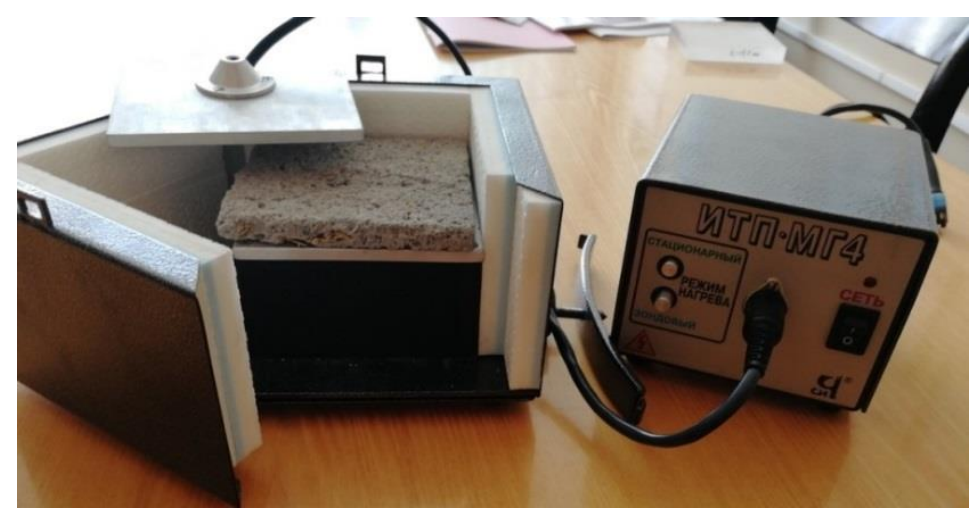

Fig. 3. Fitting of an experimental sample in the ITP MG-4 installation

Next, the thickness of the sample was entered on the keyboard of the electronic unit. The heating time of the installation was 60 minutes. The maximum heating temperature is 47.1 ${ }^{\circ} \mathrm{C}$.

The average readings of the device regarding the thermal conductivity coefficient of foamed concrete sample No. 5 amounted to $\lambda=0.138 \mathrm{~W} / \mathrm{m}^{\circ} \mathrm{C}$, and $0.127 \mathrm{~W} / \mathrm{m}^{\circ} \mathrm{C}$ for fiberreinforced concrete.

\section{Conclusion}

Foamed concrete is a multiphase structure, the phases having different densities. The difference in phase densities causes elastic stresses between the phases, this causes hardening of the structure of non-autoclave foamed concrete. The occurrence of micro-stresses at the boundaries of grains and fibers leads to the stress state of the entire structure, capable of withstanding external mechanical stresses.

It was found that the introduction of modified straw fibers with a length of $\mathrm{L}=17 \mathrm{~mm}$ reduces the shrinkage of non-autoclaved foam concrete. The introduction of $15 \%$ (consumption rate $46.5 \mathrm{~kg} / \mathrm{m}^{3}$ ) is most effective, in that case the compressive strength is increased by $28 \%$ compared to control samples.

Analyzing the test results shows that the compressive strength grade of concrete for samples No. 1,2,3,5 is B3,5-5, which is common for heat-insulating foamed concrete, and B7,5 for sample No. 4, which is typical for structural heat-insulating concrete.

The obtained NAFC with organic dispersed reinforcement is more efficient in terms of the thermophysical parameters than unreinforced non-autoclaved foamed concrete, the value of the thermal conductivity decreases by $8 \%$ compared to control samples.

Thus, the use of an organic fibrous filler in the form of a modified straw section at an optimal dosage of $15 \%$ makes it possible to obtain foamed fiber concrete with a compressive strength of up to $5.5 \mathrm{MPa}$, a bending strength of $0.21 \mathrm{MPa}$, and a thermal conductivity of $\lambda=0.127 \mathrm{~W} / \mathrm{m} \cdot{ }^{\circ} \mathrm{C}$.

The nature of the destruction of foamed fiber concrete samples in comparison with the control foamed concrete samples is more plastic. Fibers reduce shrinkage deformation, cracking load decreases up to $21 \%$.

The studies have shown that the physical and mechanical characteristics of foamed fiber 
concrete with SF in all cases exceed the performance of samples made of unreinforced foamed concrete with a similar composition. Dispersed reinforcement with an organic fiber filler allows increasing crack resistance, reducing shrinkage deformation of foamed fiber concrete and can be recommended for use in wall load-bearing products.

\section{References}

1. S.V. Kliuev, A.V. Kliuev, A.D. Abakarov, E.S. Shorstova, N.E. Gafarova, Inzhenernostroitelnyi zhurnal, 7(75), 66-75 (2017). DOI: 10.18720/MCE.75.6

2. R.V. Serova, G.M. Rakhimova, E.A. Stasilovich, S.Zh. Epokha nauki, 14, 192-200 (2018). DOI 10.1555/2409-3203-2018-0-14-192-2.

3. I.N. Shirinzade, N.M. Akhmedov, Mezh-dunarodnyi nauchno-issledovatelskii zhurnal, 3(57), 107-114 (2017). DOI: https://doi.org/ 10.23670/IRJ.2017.57.125.

4. F.N. Rabinovich, S.M. Babaev, Promyshlennoe i grazhdanskoe stroitelstvo, 8, 28-31 (2009). DOI: 10.33622/0869-7019.

5. V.G. Solovev, E.A. Shuvalova, Mezhdunarodnyi nauchno-issledovatelskii zhurnal, 9(63), 78-81 (2017). DOI: https://doi.org/10.23670/IRJ.2017.63.065.

6. F.I. Fedorov, A.E. Mestnikov, Promyshlennoe i grazhdanskoe stroitelstvo, 1, 48-52 (2018). DOI: 10.33622/0869-7019.

7. F.I. Fedorov, A.E. Mestnikov, Promyshlennoe i grazhdanskoe stroitelstvo, 8, 22-25 (2016). DOI: 10.33622/0869-7019.

8. N.Z. Zakaria, M.Z. Sulieman, R. Talib, International Journal of Advanced Engineering, Management and Science, 1(8), 24-31 (2015).

9. Y.H. Mugahed Amran, N. Farzadnia, A.A. Abang Ali, Construction and Building Materials, 101, 990-1005 (2015). DOI: 10.1016/j.conbuildmat.2015.10.112.

10. Y.H. Mugahed Amran, H. Alabduljabbar, M.H.R. Khudhair, F. Hejazid, A. Alaskare, F. Alrshoudie, A. Siddikaf, Results in engineering, 5, 1-10 (2020). https://doi.org/10.1016/j.rineng.2019.100092.

11. D. Falliano, D. Domenico, G. Ricciardi, E. Gugliandolo, Construction and Building Materials, 198, 479-493 (2019). https://doi.org/10.1016/j.conbuildmat.2018.11.197. (http://www.sciencedirect.com/science/article/pii/S0950061818328915)

12. E. T. Dawood, Y. Z. Mohammad, W. A. Abbas, M. A. Mannan, Heliyon, 4(12), 2018. https://doi.org/10.1016/j.heliyon.2018.e01103

13. K.V. Sabarish, J. Jones et al., Materials Today: Proceedings (2019). https://doi.org/10.1016/j.matpr.2019.07.686.

14. D. Falliano, D. Domenico, G. Ricciardi, E. Gugliandolo, Composite Structures, 209, 4559 (2019). https://doi.org/10.1016/j.compstruct.2018.10.092.

15. M.A. Othuman Mydin, N. Mohd Zamzani, A.N. Abdul Ghani, Data in Brief, 25 (2019). https://doi.org/10.1016/j.dib.2019.104320. 